\begin{tabular}{cc|c}
\hline Tar. Bil. Der. & Tarım Bilimleri Dergisi & Journal of Agricultural Sciences \\
& $\begin{array}{c}\text { Dergi web sayfası: } \\
\text { www.agri.ankara.edu.tr/dergi }\end{array}$ & Journal homepage: \\
& www.agri.ankara.edu.tr/journal
\end{tabular}

\title{
Türk Saanen Keçilerinde Elle Sağım ile Makineli Sağımın Süt Verimi, Süt Bileşenleri ve Kalıntı Süt Bakımından Karşılaştırılması
}

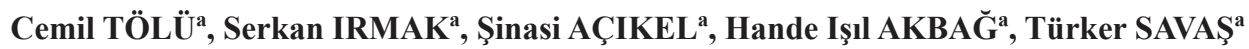 \\ ${ }^{a}$ Çanakkale Onsekiz Mart Üniversitesi, Ziraat Fakültesi, Zootekni Bölümü, 17020, Çanakkale, TÜRKIYE
}

\section{ESER BILGISİ}

Araştırma Makalesi

DOI: 10.1501/Tarimbil_0000001404

Sorumlu Yazar: Cemil TÖLÜ, E-posta: cemiltolu@comu.edu.tr, Tel: +90 (286) 2180018

Geliş Tarihi: 08 Ocak 2015, Düzeltmelerin Gelişi: 13 Temmuz 2015, Kabul: 13 Temmuz 2015

\section{ÖZET}

Süt sığırlarına benzer şekilde uzun laktasyon süresine sahip olan süt tipi keçilerin makineli sağımı hakkında ülkemizde önemli ölçüde bilgi üretimine gereksinim bulunmaktadır. Bu çalışmada, Türk Saanen keçilerinde makineli sağım ve elle sağım, süt verimi ve süt bileşenleri bakımından karşılaştırılırken, ayrıca makineli sağımda memede kalan "kalıntı süt" miktarı ve bileşenleri incelenmiştir. Çalışma, laktasyonlarının 5. ayında bulunan 3-4 yaşlı 24 baş keçi üzerinde yürütülmüştür. On altı baş keçi elle ve makine ile sağımın yapıldığı sekizer başlı iki gruba ayrılırken, diğer sekiz baş keçiden makine ile sağımdan sonra memede kalan süt elle sağılarak alınmıştır. Süt bileşenleri Milk-Lab Minor süt analiz cihazıyla tespit edilirken, yağ analizi ayrıca Gerber yağ analiz cihazı ile de yapılmıştır. Keçilerde sağım denetimlerinde periyot başına belirlenen süt verimleri elle $(1.073 \mathrm{~L})$ ve makineli sağımda $(1.095 \mathrm{~L})$ birbirine benzer bulunmuştur $(\mathrm{P}=0.8807)$. Sabah sağımında akşam sağımına göre $140 \mathrm{~mL}$ daha fazla süt alınırken, akşam sağımında elde edilen süt, daha yüksek oranda süt bileşenlerine sahip olmuştur $(\mathrm{P}<0.0001)$. Elle sağımda elde edilen süt, makineli sağımda elde edilen süte göre daha yüksek oranda süt bileşenlerine sahip olurken, Milk-Lab Minor ile yapılan yağ analizi önemli ölçüde farklılaşmıştır ( $\mathrm{P}=0.0317)$. Makineli sağımdan sonra 224-262 mL ve ortalama \% 22.6 kalıntı süt elde edilmiştir. Kalıntı sütteki süt yağı, makineli sağımdaki süte göre akşam sağımında \% 43-46, sabah sağımında ise \% 75 daha fazla orana sahip olurken, yağsız kuru madde (YKM), protein ve laktoz oranları kalıntı sütte \% 3-4 daha düşük olmuştur. Bu anlamda özellikle makineli sağımdan sonra kalıntı sütün elle sağımla memeden alınması veya makineli sağımda memede bu ölçüde sütün kalmaması adına sağım ünitesinde düzenlenmelere ihtiyaç olduğu belirlenmiştir. Süt yağı Gerber analizinde ortalama \% 3.63 olurken, Milk-Lab Minor cihazı ile ortalama \% 3.80 olarak belirlenmiştir $(\mathrm{P}<0.0001)$. Ayrıca Gerber ile Milk-Lab Minor yağ analiz değerleri arasında pozitif bir korelasyon katsayısı olduğu görülmüştür $(r=0.91 ; \mathrm{P}<0.0001)$.

Anahtar Kelimeler: Türk Saanen; Akşam sağımı; Sabah sağımı; Kalıntı süt; Süt yağ1

\section{Comparison of Milk Yield, Milk Composition and Residual Milk of Machine and Hand-Milked in Turkish Saanen Goats}

\section{ARTICLE INFO}

Research Article

Corresponding Author: Cemil TÖLÜ, E-mail: cemiltolu@comu.edu.tr, Tel: +90 (286) 2180018

Received: 08 January 2015, Received in Revised Form: 13 July 2015, Accepted: 13 July 2015 


\begin{abstract}
Dairy goats have quite long lactation periods like dairy cows, but there is significant lack of knowledge and information about machinery milking of goats. The present study was conducted to compare milk yields and milk components in manual and machinery milking of Turkish Saanen goats and to investigate the amount of "residual milk" and milk components of machinery milking. Experiments were carried out on 24 goats aged 3-4 years and on the 5th month of their lactation period. Of these goats, sixteen were separated in groups of eight goats. The first group was hand-milked and the other group was milked with a milking machine. The remaining eight were also milked with a milking machine and then the residual milk in udders was hand-milked. Milk components were analyzed with Milk-Lab Minor milk analysis device and fat analysis was carried out with Gerber fat analysis device. Milk yields of milking periods were similar in hand milking $(1.105 \mathrm{~L})$ and machinery milking $(1.095 \mathrm{~L})(\mathrm{P}=0.8807)$. While morning milking had $140 \mathrm{~mL}$ more milk than evening milking, evening milk had higher component values than morning milk $(\mathrm{P}<0.0001)$. Hand milk also had higher component values than machinery milk and significant differences were observed in fat values determined with Milk-Lab Minor $(\mathrm{P}=0.0317)$. Residual milk after machinery milking was found to be $224-262 \mathrm{~mL}$ and $22.6 \%$. Milk fat ratio of residual milk was $43-46 \%$ higher than evening machinery milk, $75 \%$ higher than morning machinery milk and residual milk had $3-4 \%$ higher non-fat dry matter (NFDM), protein and lactose contents. Thus, residual milk after machinery milking should manually be milked up and arrangements should be made on milking units to reduce such high amounts of residual milk. While milk fat ratio was 3.63\% in Gerber analysis, the value was observed as $3.80 \%$ in Milk-Lab Minor device $(\mathrm{P}<0.0001)$. A positive correlation coefficient was observed between Gerber and Milk-Lab Minor fat values $(\mathrm{r}=0.91 ; \mathrm{P}<0.0001)$.
\end{abstract}

Keywords: Turkish Saanen; Evening milking; Morning milking; Residual milk; Milk fat

(C) Ankara Üniversitesi Ziraat Fakültesi

\section{Giriş}

Önceki y1llarda Akdeniz ülkelerinde genellikle ekstansif koşullarda süt üretimi amaçlı keçi yetiştiriciliği yapılırken (Morand-Fehr et al 1983), son y1llarda dünyada ve ülkemizde entansif süt keçiciliği yaygınlaşmaktadır. $\mathrm{Bu}$ üretimde sütün tamamının hijyenik koşullarda ve hayvanın meme dokusuna zarar vermeden sağılması öncelikli amaçtır. Süt keçiciliğinde süt kalitesi, zaman ve iş gücü tasarrufu gibi sebeplerden dolayı makineli sağımın elle sağıma göre avantajlı olduğu bilinmektedir (Boyazoglu \& Morand-Fehr 2001; Caroprese et al 2007; Tölü \& Savaş 2008). Ancak makineli sağımda da makinenin basınç ve pulsasyonu, hijyen koşulları, memeden sütün tamamen alınması gibi konularda sıkıntılar oluşabilmektedir. İtalya'da keçi işletmelerinde yapılan bir çalışmada, makineli sağımın daha hijyenik olduğu, ancak az sayıdaki hayvanın elle sağıldığ işletmelerde de somatik hücre sayısının daha az olduğu belirlenmiştir (Delgado-Pertinez et al 2003).

Çiftlik hayvanlarında süt verim denetimlerindeki günlük süt verimleri sabah ve akşam süt ölçümlerinin toplamından oluşmaktadır. Süt verim kontrolü ölçümlerinde genellikle sabah sağımındaki süt miktarının akşam sağımındaki süt miktarından daha yüksek olduğu belirlenmiştir (Fuertes et al 1998; Katanos et al 2005; Pala \& Savaş 2006). Ayrica akşam sağımı ile sabah sağımı arasındaki fark, süt verimi yanında süt içerikleri bakımından da farka neden olabilmektedir (Fuertes et al 1998; Salama et al 2003).

Makineli sağım ile elle sağım karşılaştırmasında işletme ekonomisini ilgilendiren en önemli noktalar, süt verimi ve süt bileşenlerinin farklılık gösterebilmesidir. Bu konudaki çalışmalar daha ziyade koyunlarda yapılmıştır. Örneğin, Portekiz menşeli Beira Baixa koyunlarında ve Yunaninstan menşeli Boutsiko koyunlarında elle sağıma göre makineli sağım lehine süt verimi istatistiksel olarak önemli seviyede daha yüksek rapor edilmiştir (Carreiro et al 1989; Sinapis 2007). İspanyol Manchega ırkı koyunlarda yapılan diğer bir çalışmada ise, iki sağım tipinde süt verimleri birbirlerine yakın seviyede belirlenirken (Linares et al 1984), yine İspanyol Churra 1rk1 koyunlarda 
yapılan çalışmada ise, önemsiz olmakla beraber elle sağımda biraz daha fazla süt elde edilmiştir (de la Fuente et al 1997).

Süt bileşenleri bakımından makineli sağım ile elle sağım arasındaki değişebilen en önemli farklılık süt yağında gözlenmektedir (Labussiere 1988; Millogo et al 2009). Bu anlamda öncelikle sağlıklı bir sağım süreciyle memedeki sütün tamamının alınması gerekmektedir (Rushen et al 1999; Tölü \& Savaş 2008). Memede kalan süt miktarı artıkça süt yă̆ oranı da artmaktadır. Makineli sağımda memede kalan ve elle sağılarak alınan süt "kalıntı süt" olarak tanımlanmaktadır. Normal bir sağımda sütün \% 68'ini bulabilen kalıntı sütün (Anderson et al 1968) yă içeriğinin, memeden tamamen alınan süte göre \% 19-46 oranında daha yüksek olduğu belirlenmiştir (Labussiere 1988; Millogo et al 2009). Atlarda makineli sağımda elle sağıma göre önemli ölçüde daha yüksek oranda süt yağı tespit edilmiştir (Caroprese et al 2007). Dolayısıyla istenilen düzeyde süt yağı oranı ve laktasyon sonunda istenilen süt yağ veriminin elde edilmesi için memede kalan sütün tamamının uygun sağım yöntemi ile alınması gerekmektedir.

Süt yağının belirlenmesinde tüm bileşenlerin analiz edildiği cihazlar kullanıldığ gibi, sadece süt ve peynir yağı analizinde kullanılan ve dünyada en güvenilir yöntemlerden biri olan Gerber cihazı ile süt yağ 1 analiz edilebilmektedir. Saanen ve Alpine keçilerinin süt yağ 1 analizlerinde Gerber ve Foss ile yapılan analiz sonuçlarının birbirlerine yakın seviyelerde seyrettiği görülmüştür (Zan et al 2006). Ülkemizde birçok işletmede yaygın olarak kullanılan ve pratik olarak çok sayıda makro süt bileşenini aynı anda analiz edebilen süt analiz cihazlarının süt yağı analiz sonuçları ile Gerber süt yağı analiz cihazının süt yağı sonuçları arasındaki farklılık veya benzerlikler merak konusudur.

Çiftlik hayvanları içerisinde sı̆̆ırdan sonra en fazla ve en uzun süre süt üreten keçi türünde, özellikle ülkemiz için makineli sağım ile ilgili daha fazla bilgi üretimine ihtiyaç duyulmaktadır. Bu çalışmada, verim seviyesi yüksek olan ve ülkemiz için önemli bir süt tipi genotipi olan Türk Saanen keçilerinde, makineli sağım ile elle sağımın süt verimi ve süt bileşenleri karşılaştırılarak muhtemel farklıklar ve farklılıklara etkili faktörler belirlenmiştir. Ayrıca makineli sağımda memede kalan olası "kalıntı süt" miktarı ve içeriği de saptanmıştır.

\section{Materyal ve Yöntem}

\subsection{Hayvanlar ve să̆ım}

Çalı̧̧ma, Çanakkale Onsekiz Mart Üniversitesi Teknolojik ve Tarımsal Araştırmalar Merkezi (TETAM) Sarıcaeli Yerleşkesi Küçükbaş Hayvan Yetiştirme Birimi'nde, yarı entansif sistemde yetiştirilen Türk Saanen keçileriyle yapılmıştır. Yaklaşı 250 da alana sahip olan merada, 30 da alan çalılık formdadır. Sabah ve akşam saatlerindeki sağımlarda pelet formdaki süt yemi $(\% 88.14 \mathrm{KM}$; \% $15.84 \mathrm{HP} ; 2600 \mathrm{kcal} \mathrm{ME}$ ) bireysel olarak toplam $1 \mathrm{~kg}$ baş$^{-1}$ sunulurken, sabah sağımından sonra misir silaj1 (\% $27.69 \mathrm{KM}$; \% $9.15 \mathrm{HP} ; 2500 \mathrm{kcal}$ $\mathrm{ME)}$ günlük $2 \mathrm{~kg}$ baş $^{-1}$ grup koşullarında verilmiştir. Deneme süresince keçiler 7-8 saat merada otlamışlardır. Çalışma, 3-4 yaşlı ve laktasyonlarının 5. ayında bulunan yirmi dört baş keçi üzerinde yürütülmüştür. Çalışmada öncelikle on altı baş keçi elle ve makine ile sağımın yapıldığı sekizer başlı iki gruba ayrılmıştır. Diğer sekiz baş keçi ise öncelikle makine ile sağılmış ve hemen sonrasında memede kalan süt elle sağılmıştır. Çalışma ardışık toplam on altı günde tamamlanmıştır. Yirmi dört baş keçinin gruplara dağılımında yaş, doğum sırası, canlı ağırlık, vücut kondisyonu ve deneme öncesi yapılan aylık süt verimleri dikkate alınmıştır. Gruplarda laktasyonun ilk aylarında periyotlara göre ölçülen hayvan başına ortalama süt verimleri ise, makineli sağım grubunda $1.35 \pm 0.41 \mathrm{~L}$, elle sağım grubunda $1.33 \pm 0.36 \mathrm{~L}$ ve kalıntı süt grubunda ise $1.32 \pm 0.45 \mathrm{~L}$ olarak belirlenmiştir. Çalışmada kullanılan keçiler 20 yıldır yoğun bir genetik sslaha konu edilmektedirler. Genetik 1slah parametresi olarak verim ve verim unsurları yanı sıra meme formuna özellikle önem verilmektedir. $\mathrm{Bu}$ nedenle bu süre zarfinda meme formunda belirgin bir üniformite sağlanmıştır. Türk Saanen keçilerinde laktasyon süreleri 275.4 ile 288.4 gün ve laktasyon süt verimi $408.6 \mathrm{~kg}$ ile 
$521.6 \mathrm{~kg}$ arasında değişmektedir (Tölü et al 2010). Çalışmada sağımlar 2 x 12 paralel tipteki küçükbaş süt sağım ünitesinde, sabah 07:00-08:00 ve akşam 18:00-19:00 saatleri arasında gerçekleştirilmiş̧ir. Elektronik pulsatörlü sağım ünitesi, $2000 \mathrm{~L} \mathrm{dak}^{-1}$ kapasiteli vakum pompasına sahip, $40 \mathrm{kPa}$ vakum seviyesinde 60:40 nabız oranında dakikada 90 nabız sayısı ile çalışmaktadır (Gürhan \& Çetin 2003). Sağım yapılırken süt akışı sürekli takip edilmiş ve süt akışı bittikten sonra sağım başlıkları meme başlarından manüel olarak çıkartılmıştır. Aynı kişi tarafından yapılan elle sağımda avuç içi sağım yöntemi kullanılmıştır. Makine ile sağımda süt ölçümü, sistemin ICAR onaylı mekanik sütölçeri ile yapılırken, elle sağımda bir kovaya alınan süt 2 g’a duyarlı terazide ölçülmüştür. Tartılan sütün özgül ağırlığı $1.030 \mathrm{~g} \mathrm{~mL}^{-1}$ olarak alınmış ve litreye dönüştürülmüştür (da Costa et al 2014). Yapılan süt ölçümlerinden hemen sonra $25 \mathrm{~mL}$ kapla her bir keçiye ait süt örneği alınarak laboratuar ortamında analiz edilmiştir. Öncelikle Milk-Lab Minor süt analiz cihazında (Milk-Lab Minor ${ }^{\circledR}$ ) yağ, protein, laktoz, yağsız kuru madde (YKM) oranları belirlenmiş (Tölü et al 2012), akabinde Gerber süt yağı analiz cihazı ile süt yağı oranı tespit edilmiştir (Metin 2006; Anonim 2014). Süt verimi ve içeriği ile ilgili tüm ölçüm ve analizler aynı şekilde kalıntı süt belirlenmesinde de uygulanmıştır.

\subsection{Süt analizleri}

Gerber süt yağ analizi yöntemi, bütirometre ad1 verilen ölçekli özel cam tüpte, belirli hacimdeki sütün protein ve zor çözünen tuzlarının derişik sülfürik asit ve amil alkol kullanılarak çözündürülmesi ve yağın parçalanması prensibine dayanır. Serbest hale geçen yağın santrifüj yardımıyla ayrılması sağlanır. Santrifüj işlemi sonrası bütirometrenin ölçekli kısmında okuma yapılarak, örnekteki yağ miktarı \% olarak ifade edilir (Metin 2006; Anonim 2014). MilkLab Minor süt analiz cihazı, hızlı sonuç vermesi ve diğer manüel yöntemlerle kıyaslandığında pratik, masrafsız ve iş gücünden tasarruf sağlaması gibi konularda avantaja sahiptir. Cihaz birçok parametreyi aynı anda okuyabilmektedir. Cihazla YKM, yağ, protein, laktoz, yoğunluk parametrelerine bakılabilmektedir. Söz konusu cihaz ultrasonik ölçüm prensibi ile çalışmaktadır. Süt örneği içerisine ultrasonik ses dalgaları gönderilmekte ve cihaz, ses dalgalarının süt içerisindeki geçiş hızına göre okuma yapmaktadır. Okumada süt sicaklığının $10-25{ }^{\circ} \mathrm{C}$ arasında olması önerilmektedir. Sonuç \% olarak verilmektedir (Anonim 2010).

\subsection{Istatistiksel analizler}

Süt verimi ve bileşenlerinin istatistiksel analizinde tekrarlamalı ölçümler varyans analizinden yararlanılmıştır. Analizlerde Eşitlik 1 kullanılmıştır. Yapılan ön analizlerde tüm interaksiyonlar istatistiksel olarak önemsiz $(\mathrm{P}>0.05)$ olduğu için son analizlerde interaksiyonlar modelden çıkartılmıştır. Çoklu karşılaştırmalarda TUKEY testinden yararlanılan analizler SAS (1999) istatistik paket programı ile gerçekleştirilmiştir.

$\mathrm{y}_{\mathrm{ijklm}}=\mu+\mathrm{T}_{\mathrm{i}}+\mathrm{G}_{\mathrm{j}}+\mathrm{P}_{\mathrm{k}}+\mathrm{k}_{\mathrm{jl}}+\mathrm{e}_{\mathrm{ijklm}}$

Burada; $y_{i j k l m}$, i'inci ölçüm gününde, j'inci gruptaki, k'inci periyotta l'inci keçiye ait m'inci süt miktarı veya süt bileşenleri oranını; $T$, i'inci ölçüm gününün sabit etkisini $(i=1, \ldots, 16) ; \mathrm{G}_{\mathrm{j}}$, $\mathrm{j}$ 'inci grubun etkisini ( $j=$ elle sağım, makineyle sağım); $P_{k}, k^{\prime} ı n c 1$ periyodunun sabit etkisini ( $\mathrm{k}=\mathrm{sabah}$, akşam); $\mathrm{k}_{\mathrm{j} \text {, }}$ j'inci gruptaki l'inci keçinin şansa bağlı etkisini (l= $1, \ldots, 16) ; \mathrm{e}_{\mathrm{ijklm}}$, şansa bağlı hatayı ifade etmektedir.

Süt yağ analizi yöntemlerinin karşılaştırıldığı istatistiksel analizlerde ise Eşitlik (2) kullanılmıştır.

$\mathrm{y}_{\mathrm{ijkkmn}}=\mu+\mathrm{T}_{\mathrm{i}}+\mathrm{G}_{\mathrm{j}}+\mathrm{P}_{\mathrm{k}}+\mathrm{Y}_{1}+\mathrm{b}\left(\bar{x}-x_{i j k l m n}\right)+\mathrm{k}_{\mathrm{jm}}+\mathrm{e}_{\mathrm{ijklmn}}$

Burada; farklı olarak $\mathrm{Y}_{1}$, l'inci süt yağ1 yönteminin etkisini (l= Milk-Lab Minor, Gerber); $\mathrm{b}$, süt miktarının süt yağ oranı üzerine regresyon katsayısını; $\bar{x}$, süt miktarı ortalamasını ve $x_{i j k l m n}$, i'inci ölçüm günündeki, j'inci grubtaki, k'inc1 periyottaki, l'inci süt yağı analiz yöntemindeki, m'inci keçinin, n'inci süt miktarı değerini ifade etmektedir.

\section{Bulgular ve Tartışma}

Türk Saanen keçilerinde sağım başına süt veriminin sağım tiplerine göre benzer seviyede olduğu belirlenmiştir (Çizelge $1 ; \mathrm{P}=0.8807$ ). $\mathrm{Bu}$ çalışmadaki bulgulara benzer şekilde koyunlarda yapılan çalışmalarda makineli ve elle sağımdaki 
süt miktarlarının birbirlerine yakın olduğu rapor edilmiştir (Linares et al 1984; de la Fuente et al 1997). Bazı diğer çalışmalarda ise makineli sağımda, elle sağıma göre süt veriminin daha yüksek olduğu, koyunlarda (Carreiro et al 1989; Sinapis 2007) ve atlarda (Caroprese et al 2007) tespit edilmiştir. Keçilerde süt veriminin elle ve makineli sağıma göre doğrudan karşılaştırıldığı bir çalışmaya ulaşılamamıştır.

Keçilerde sabah sağımında akşam sağımına göre daha yüksek süt elde edildiği bildirilmektedir (Katanos et al 2005; Pala \& Savaş 2006). Bu çalışmada da sabah sağımında akşam sağımından $140 \mathrm{~mL}$ daha fazla süt sağılmıştır $(\mathrm{P}<0.0001)$. Ancak bu çalışmada sabah sağımı ile akşam sağımı arasında geçen sürenin akşam sağımı ile sabah sağımı arasındaki süreden yaklaşık bir saat daha fazla olduğu unutulmamalıdır. Sabah ve akşam sağımları arasındaki süt verimi farkı söz konusu süre farklarından kaynaklanabileceği gibi, iki sağım arasında süreler eşit dahi olsa sabah ve akşam sağımları arasında fark oluşabilmektedir. Bunun muhtemel nedeninin, hayvanların gece daha fazla dinlenme ve gündüz tükettiği besinin sindirimine daha fazla vakit ayırması olabileceği düşünülmüştür.

Süt bileşenlerinden sadece Milk-Lab Minor ile yapılan yağ analizi sağım tiplerine göre önemli ölçüde farkl1lık gösterirken $(\mathrm{P}=0.0317)$, periyotlara göre süt bileşenlerinin tamamında önemli farklılık bulunmuştur (Çizelge 1; $\mathrm{P}<0.0001$ ). Sinapis (2007), elle sağıma göre makineli sağımda önemli düzeyde daha fazla süt miktarı belirlemiş, ancak önemli bulunmamakla beraber elle sağımda daha yüksek oranda yağ, protein ve laktoz bulunduğunu bildirmiştir. $\mathrm{Bu}$ durumun, süt miktarı artıkça süt bileşenleri oranının düşmesinden kaynaklandığ 1 bildirilmiştir (Katanos et al 2005; Tölü et al 2010). Ancak atlarda makineli sağımda daha yüksek süt miktarı elde edilmesine karşın, daha kısa sağım süresinden kaynaklanarak, önemli ölçüde daha yüksek yă̆ oranı bulunmuştur (Caroprese et al 2007). Dolayısıyla özellikle yağ içeriği oranı süt miktarından etkilendiği ölçüde, süt sağım hızı ve sütün memeden tamamen alınması ile de ilişkilidir. Mevcut çalışmada da memede kalan süt miktarı daha az olan elle sağımda süt yağ $(\mathrm{P}=0.0317)$ ve diğer bileşenler makineli sağıma göre daha yüksek oranlarda belirlenmişlerdir (Çizelge 1). Benzer durum periyotlar bakımından akşam sağımı lehine gerçekleşmiştir $(\mathrm{P}<0.0001)$. Sağım süresi birbirine yakın gerçekleşen elle (102 sn) ve makineyle $(114 \mathrm{sn})$ sağım arasında ve yine periyotlar arasında süt bileşenleri farklarının süt miktarından kaynaklandığg söylenebilir. Nitekim elle ve makine ile sağım benzer süt verimine sahipken, makineli sağımda memede kalan \% 22.6 oranındaki süt miktarı (Çizelge 2) nedeniyle süt bileşenleri oranı daha düşük düzeylerde gerçekleşmiş olabilir. Farklı keçi ırklarında yapılan ve bu çalışmadakine benzer

Çizelge 1- Grup ve periyotlara göre süt verimi ve süt bileşenlerine ait en küçük kareler ortalamaları (EKKO), standart hataları (SH) ve P değerleri

Table 1- The least square means (EKKO), standard errors (SH) and P values of milk yield and milk components according to groups and periods

\begin{tabular}{|c|c|c|c|c|c|c|c|c|c|c|c|}
\hline \multirow[t]{2}{*}{ Özellikler } & \multicolumn{2}{|c|}{ Elle sağım } & \multicolumn{2}{|c|}{$\begin{array}{c}\text { Makineyle } \\
\text { sağım }\end{array}$} & \multirow[b]{2}{*}{$P$} & \multicolumn{2}{|c|}{ Akşam } & \multicolumn{2}{|c|}{ Sabah } & \multicolumn{2}{|r|}{$\begin{array}{l}\text { Ölçüm } \\
\text { günleri }\end{array}$} \\
\hline & EKKO & $\mathrm{SH}$ & EKKO & SH & & EKKO & $S H$ & EKKO & $\mathrm{SH}$ & $P$ & $P$ \\
\hline Süt verimi (L) & 1.07 & 0.10 & 1.09 & 0.10 & 0.8807 & 1.01 & 0.07 & 1.15 & 0.07 & $<0.0001$ & 0.7713 \\
\hline Süt yağ ${ }^{1}(\%)$ & 3.91 & 0.21 & 3.57 & 0.23 & 0.2884 & 3.98 & 0.16 & 3.50 & 0.16 & $<0.0001$ & 0.1783 \\
\hline Süt yağ ${ }^{2}(\%)$ & 4.05 & 0.15 & 3.57 & 0.15 & 0.0317 & 4.07 & 0.11 & 3.55 & 0.11 & $<0.0001$ & 0.0052 \\
\hline YKM (\%) & 7.72 & 0.08 & 7.59 & 0.08 & 0.2939 & 7.75 & 0.06 & 7.56 & 0.06 & $<0.0001$ & $<0.0001$ \\
\hline Süt proteini & 2.82 & 0.03 & 2.77 & 0.03 & 0.3209 & 2.83 & 0.02 & 2.76 & 0.02 & $<0$. & $<0.0001$ \\
\hline Laktoz (\%) & 4.25 & 0.04 & 4.17 & 0.04 & 0.2698 & 4.26 & 0.03 & 4.15 & 0.03 & $<0.0001$ & $<0.0001$ \\
\hline
\end{tabular}

1, Gerber; 2, Milk-Lab Minor; YKM, yağsız kuru madde 
biçimde sabah sağımında daha fazla süt miktarı belirlenen bir çalışmada, akşam sağımında süt yağı, süt proteini ve laktoz (bir ırk dışında) içerikleri, sabah sağımından çok daha yüksek seviyede belirlenmiştir (Katanos et al 2005).

Çalışmada makine ile yapılan sağımdan hemen sonra yapılan elle sağımda periyotlara göre değişmekle beraber 224-262 mL arasında kalıntı süt tespit edilmiştir (Çizelge 2). Bu miktar sağılabilen toplam sütün \% 22.6'sıdır. Makineli sağımda süt ile kalıntı süt arasında pozitif korelasyon $(\mathrm{r}=0.27)$ tespit edilmiştir $(\mathrm{P}=0.0018)$. Katanos et al (2005) farklı keçi rrkları üzerinde yürüttükleri çalışmada, makineli sağımdaki günlük toplam kalıntı süt miktarını $228-298 \mathrm{~mL}$ ve oranını ise \% 19.8-29.9 arasında belirlemişlerdir. Ayrıca günde iki öğün sağım ile bir öğün sağımın Tinerfena süt tipi keçilerinde karşılaştırıldığı çalışmada, iki öğün sağımda kalıntı süt miktarının haftalara göre değişerek ortalama 150-320 mL (\% 5.1-10.9) arasında olduğunu bildirilmiştir (Capote et al 2008). Aynı çalışmada ayrıca süt miktarının daha fazla olduğu günlük tek sağımda, kalıntı süt miktarı da daha yüksek olmuştur. Kalıntı süt oranı farklı keçi ırklarında \% 11.61-14.49 arasında değişmiştir (Torres et al 2013). Anderson et al (1968) ineklerde kalıntı süt oranının ortalama olarak $\%$ 0.72-37.6 arasında değiştiğini ve kalıntı süt ile makineli sağımda elde edilen süt arasındaki korelasyon katsayısını, önemsiz bulmakla beraber $\mathrm{r}=0.41$ olarak tespit etmişlerdir. Bu çalışmada, süt verimi sağım yöntemlerine göre birbirine yakın seviyede gerçekleşmiş olsa da (Çizelge 1), kalıntı süt oranının sağılan süt miktarının \% 22.6's1 olması, makineli sağımda uygun vakum, nabız sayısı ve nabız oranları ile memeden uygun zamanda sütün alındığını, ancak belli bir seviyenin altında mutlaka memede sütün kalabileceğini göstermektedir. Nitekim çalışmada kullanılan sağım ünitesinde sağım esnasında süt akışının görülmemesine rağmen, sağım başlıklarının memeden çıkartılmasından hemen sonrasında yapılan elle sağımda önemli miktarda süt tespit edilmiştir (Çizelge 2). Muhtemelen elle sağıma göre daha kuvvetli bir vakum ile sütün alındığ 1 makineli sağımda, sağım esnasında daha fazla süt üretiliyor da olabilir. Memenin anatomik farkından kaynaklansa gerek, kalıntı süt, keçilere göre sığırlarda çok daha fazla sorun oluşturmaktadır. $\mathrm{Bu}$ anlamda sığırlarda, sağılan sütün \% 68'ine ulaşabilen kalıntı süt miktarını azaltmak amacıyla sağım öncesi oksitosin hormonu yaygın biçimde kullanılmaktadır (Anderson et al 1968). Keçilerde ise sığırlardan farklı olarak, meme sarnıcı boşluğunun (cisternal), alveol meme boşluğuna göre daha fazla paya sahip olması nedeniyle (Salama et al 2004) oksitosin enjeksiyonu tam anlamıyla sonuç vermeyebilmektedir (Bruckmaier et al 1994; Torres et al 2014).

Makineli sağımda elde edilen süt ile kalıntı sütteki besin madde bileşenlerinin önemli ölçüde birbirinden farklılık gösterdiği belirlenmiştir (Çizelge 2; $\mathrm{P} \leq 0.05$ ). Kalıntı sütteki süt yağının, periyotlara göre değişmekle beraber \% $\quad 43-75$ oranında makineli sağımdaki sütten daha yüksek seviyede olduğu görülürken, yağsız kuru madde (YKM), protein ve laktoz içeriklerinin \% 3-4 oranında daha düşük olduğu tespit edilmiştir $(\mathrm{P} \leq 0.05)$. Farklı hayvan türlerinde yapılan çalışmalarda kalıntı sütün, sağımdan elde edilen süte göre \% 19-46 oranında daha fazla yağ içeriğine sahip olduğu belirlenmiştir (Labussiere 1988; Millogo et al 2009). Bu çalışmada akşam sağımındaki kalıntı süt yağ oranları farkı (\% 4346) diğer çalışmalarla benzer iken, özellikle sabah sağımında kalıntı sütlerdeki \% 75'lik oran farkı bir hayli dikkat çekicidir. Bu sebeple özellikle sabah sağımındaki kalıntı sütlerin memeden tamamen alınması çok daha fazla önem arz etmektedir. Süt sığırlarında yapılan çalışmada kalıntı sütteki yağ oranı makineli sağımdaki süte göre 2-2.5 kat daha fazla yağ içeriğine sahip olurken, YKM oranları benzer bulunmuştur (Anderson et al 1968). Farkl1 keçi irklarında alveol meme boşluğundan alınan sütteki yă oranının meme sarnıcı (cisternal) boşluğundan elde edilen süte göre çok daha yüksek olduğu ve bu çalışmadaki bulgulara benzer şekilde YKM, protein ve laktoz bileşenlerinin birilerine yakın düzeylerde olduğu tespit edilmiştir (Torres et al 2012). 
Çizelge 2- Periyotlara göre kalıntı sütün miktar ve bileşenlerine ait ortalamaları $(\bar{x})$, standart hataları (SH) ve kalıntı sütün makineli süte oranları (\%)

Table 2- The means $(\bar{x})$, standard errors (SH) and the ratios of residual milk to machine milking of residual milk amount and milk components according to periods

\begin{tabular}{lcccccc}
\hline \multirow{2}{*}{ Özellikler } & \multicolumn{2}{c}{ Akşam } & $\begin{array}{c}\text { Makineli sağımdaki } \\
\text { süte oranı }\end{array}$ & Sabah & $\begin{array}{c}\text { Makineli să̆ımdaki } \\
\text { süte oranı }\end{array}$ \\
\cline { 2 - 7 } & $\bar{x}$ & SH & $\%$ & $\bar{x}$ & SH & $\%$ \\
\hline Süt verimi (L) & 0.22 & 0.02 & 22.51 & 0.26 & 0.02 & 22.67 \\
Süt yağ1 ${ }^{1}(\%)$ & 5.20 & 0.14 & 146.06 & 5.44 & 0.14 & 175.48 \\
Süt yağ12 (\%) & 5.46 & 0.16 & 143.68 & 5.72 & 0.16 & 175.46 \\
YKM (\%) & 7.50 & 0.05 & 94.22 & 7.32 & 0.05 & 96.31 \\
Süt proteini (\%) & 2.83 & 0.01 & 97.25 & 2.67 & 0.01 & 96.04 \\
Laktoz (\%) & 4.26 & 0.02 & 97.48 & 4.03 & 0.02 & 96.41 \\
\hline
\end{tabular}

1, Gerber; 2, Milk-Lab Minor; YKM, yağsız kuru madde

Süt verimi ile süt bileşenleri arasında, YKM dişında negatif yönde bir ilişkinin olduğu belirlenmiştir (Çizelge 3). Özellikle süt yağı oranının süt verimi artıkça önemli ölçüde düştüğü görülmüştür ( $r=-0.47 ; \mathrm{r}=-0.48 ; \mathrm{P}<0.0001)$. Gerber yöntemi ile süt yağ 1 tüm gruplarda ortalama $\%$ 3.63 \pm 0.11 olurken, Milk-Lab Minor cihazı ile $\% 3.80 \pm 0.10$ olarak belirlenmesine karşın $(\mathrm{P}<0.0001)$, iki yöntem arasında pozitif yönde bir ilişki ( $r=$ 0.91) tespit edilmiştir $(\mathrm{P}<0.0001)$. Burada her ne kadar ortalamalar arasındaki fark istatistiksel açıdan önemli olsa da, veri sayısının yüksekliği ve varyasyonun düşüklüğü nedeniyle çok küçük farklar dahi istatistiksel açıdan önemli farka işaret edebilir. Öte yandan iki yöntem arasındaki korelasyon katsayısının büyüklüğü, pratik olarak birçok farklı parametrenin belirlenebildiği MilkLab Minor cihazının keçi sütünde yağ analizi için kullanılabileceğini göstermektedir. Benzer şekilde Gerber ve Foss cihazlarında Saanen ve Alpine keçilerinin süt yağı oranı birbirine yakın değerlerde bulunmuştur (Zan et al 2006). Gerber ile yapılan yağ analizi oranı diğer süt bileşenleri ile önemli ölçüde negatif korelasyona sahip olurken $(\mathrm{P}<0.0001)$, Milk-Lab Minor cihazından elde edilen süt yă oranının diğer bileşenlerle korelasyonu önemsiz

Çizelge 3- Süt verimi ve süt bileşenleri arasındaki pearson korelasyon katsayısı (diagonalin üstü) ve $\mathbf{P}$ (diagonalin altı) değerleri

Table 3- Pearson correlation coefficient (above the diagonal) and P values (under the diagonal) between milk yield and milk components

\begin{tabular}{|c|c|c|c|c|c|c|}
\hline Özellikler & $\begin{array}{l}\text { Süt verimi } \\
(L)\end{array}$ & $\begin{array}{c}\text { Sütyă̆gl} \\
(\%)\end{array}$ & $\begin{array}{c}\text { Sütyă̆g } \\
(\%)\end{array}$ & $\begin{array}{c}Y K M \\
(\%)\end{array}$ & $\begin{array}{c}\text { Süt proteini } \\
(\%)\end{array}$ & $\begin{array}{c}\text { Laktoz } \\
(\%)\end{array}$ \\
\hline Süt verimi (L) & & -0.47 & -0.48 & -0.01 & -0.09 & -0.10 \\
\hline Süt yağ ${ }^{1}(\%)$ & $<0.0001$ & & 0.91 & -0.20 & -0.20 & -0.16 \\
\hline Süt yağ1 ${ }^{2}(\%)$ & $<0.0001$ & $<0.0001$ & & -0.03 & -0.01 & 0.02 \\
\hline YKM (\%) & 0.8651 & $<0.0001$ & 0.2488 & & 0.85 & 0.84 \\
\hline Süt proteini (\%) & 0.0037 & $<0.0001$ & 0.7215 & $<0.0001$ & & 0.98 \\
\hline Laktoz $(\%)$ & 0.0014 & $<0.0001$ & 0.4833 & $<0.0001$ & $<0.0001$ & \\
\hline
\end{tabular}

1, Gerber; ${ }^{2}$, Milk-Lab Minor; YKM, yağsız kuru madde 
bulunmuştur. Süt proteini ile laktoz arasında pozitif yönde ve önemli doğrusal korelasyon $(r=0.98$; $\mathrm{P}<0.0001$ ) tespit edilmiş ve $\mathrm{YKM}$ 'nin de kendisini oluşturan protein ve laktoz oranları ile korelasyon katsayıları sırasıyla $\mathrm{r}=0.85$ ve $\mathrm{r}=0.84$ pozitif yönde önemli bulunmuştur $(\mathrm{P}<0.0001)$.

\section{Sonuçlar}

Süt tipi bir keçi genotipi olan ve ülkemizin birçok bölgesine yayılmış Türk Saanen keçilerinde elle sağım ile makineli sağım arasında önemli bir farklılık tespit edilmemiştir. Akşam sağımı ile sabah sağımı arasında önemli ölçüde değişiklik gösteren süt verimi, sabah sağımında daha yüksek olarak belirlenmiştir. Sağım tiplerinin önemli ölçüde farklılaşmadığı keçilerde, makineli sağımdan hemen sonra yapılan elle sağımla \% 22.6 oranında kalıntı süt olduğu ve sağılan süt miktarı artıkça kalıntı süt miktarının da arttığı görülmüştür. $\mathrm{Bu}$ anlamda aile işletmelerinde makineli sağım sonrasında memelerin kontrol edilerek memede kalan sütlerin elle sağılması yoluna gidilebilir. Diğer yandan makineli sağımda bu düzeyde süt kalmaması için meme dokusuna zarar vermeyecek biçimde sağım ünitesinde düzenleme ve kontroller yapılmalıdır. Zira kalıntı sütte özellikle süt yağı, makineli sağımdaki süte göre \% 43-75 daha yüksek orandadır. Gerber cihazı ve Milk-Lab Minor cihazında yapılan süt yağı analizi arasında yalnızca \% 0.17'lik bir farkın bulunması ve iki yöntem arasındaki korelasyonun yüksekliği, Milk-Lab Minorın süt yağı analizinde rahatlıkla kullanılabileceğini göstermektedir.

\section{Teşekkür}

Yazarlar, süt analizleri aşamasında malzeme ve bilimsel destek sunan Dr. Onur GÜNEŞER'e teşekkür ederler.

\section{Kaynaklar}

Anderson R R, Hindery G A, Parkash V \& Turner C W (1968). Effectiveness of subcutaneously administered oxytocin upon removal of residual milk. Journal of Dairy Science 51(4): 601-605
Anonim (2010). www. milk-lab.co.uk Milk-Lab Ninor milk analyzer Operation manual.

Anonim (2014). Laboratory catalogue form milk analysis. http://funke-gerber.de/FG_Kat_ENG.pdf (18.10.2014)

Boyazoglu J \& Morand-Fehr P (2001). Mediterranean dairy sheep and goat products and their quality. A critical review. Small Ruminant Research 40: 1-11

Bruckmaier R M, Ritter C, Schams D \& Blum J W (1994). Machine milking of dairy goats during lactation: Udder anatomy, milking characteristics, and blood concentrations of oxytocin and prolactin. Journal of Dairy Research 61: 457-466

Capote J, Castro N, Caja G, Fernandez G, Briggs H \& Argüello A (2008). Effects of the frequency of milking and lactation stage on milk fractions and milk composition in Tinerfena dairy goats. Small Ruminant Research 75: 252-255

Caroprese M, Albenzio M, Marino R, Muscio A, Zezza T \& Sevi A (2007). Behavior, milk yield, and milk composition of machine and hand-milked Murgese mares. Journal Dairy Science 90: 2773-2777

Carreiro F M, Rebello de Andrade C S C \& Almeida L M (1989). Aptitude to machine milking of merino Beira Baixa ewes. II. Productive behaviour face to hand milking and machine milking. In: Eitam M (Ed.), Proceedings of the 4th International Symposium on Machine Milking of Small Ruminants, Sept. 13-19, Tel Aviv, Israel, pp. 530-544

Da Costa W K A, de Souza E L, Beltrao-Filho E M, Vasconcelos G K V, Santi-Gadelha T \& de Almeida Gadelha C A (2014). Comparative protein composition analysis of goat milk produced by the Alpine and Saanen breeds in Northeastern Brazil and related antibacterial activities. PLoS ONE 9(3): e93361. doi:10.1371/journal.pone.0093361

De la Fuente L F, San Primitivo F, Fuertes J A \& Gonzalo C (1997). Daily and between-milking variations and repeatabilities in milk yield, somatic cell count, fat, and protein of dairy ewes. Small Ruminant Research 24: 133-139

Delgado-Pertinez M, Alcalde M J, Guzman-Guerrero J L, Castel J M, Mena Y \& Caravaca F (2003). Effect of hygiene-sanitary management on goat milk quality in semi-extensive systems in Spain. Small Ruminant Research 47: 51-61

Fuertes J A, Gonzalo C, Carriedo J A \& San Primitivo F (1998). Parameters of test day milk yield and milk 
components for dairy ewes. Journal Dairy Science 81: $1300-1307$

Gürhan R \& Çetin M (2003). Küçükbaş hayvan süt sağım makinalarında nabız karakteristiklerinin PIC yardımıyla kontrolü. Tarım Bilimleri Dergisi-Journal of Agricultural Sciences 9(2): 147-152

Katanos J, Skapetas B \& Laga V (2005). Machine milking ability and milk composition of some imported dairy goat breeds and some crosses in Greece. Czech Journal of Animal Science 50(9): 394-401

Labussiere J (1988). Review of physiological and anatomical factors influencing the milking ability of ewes and the organization of milking. Livestock Production Science 18: 253-274

Linares J P, Gomez Gil J L \& Lopez J G (1984). Estudio comparativo de los metodos de ordeno en oveja Manchega [Comparative study of the milking methods in ewes Manchega]. In: Sever-Cuesta (Ed), Proceedings of the 3rd International Symposium on Machine Milking of Small Ruminants, May, 16-20, Valladolid, Spain, pp.188-197

Metin M (2006). Süt ve Mamülleri Analiz Yöntemleri (Duyusal, Fiziksel ve Kimyasal Analizler). Ege Ü. Ege MYO Yayınları No: 24, Ege Üniversitesi Basım Evi Bornova, İzmir, $439 \mathrm{~s}$

Millogo V, Ouédraogo G A, Agenäs S \& SvennerstenSjaunja K (2009). Day-to-day variation in yield, composition and somatic cell count of saleable milk in hand-milked zebu dairy cattle. African Journal of Agricultural Research 4(3): 151-155

Morand-Fehr P, Bourbouze A, Le Houerou H N, Gall C \& Boyazoglu J G (1983). The role of goats in the Mediterranean area. Livestock Production Science 10: 569-587

Pala A \& Savaş T (2006). Relationship between daily, morning, evening and peak yield and persistency in Turkish Saanen goats. Animal Science Journal 77: 532-537

Rushen J, De Passille A M B \& Munksgaard L (1999). Fear of people by cows and effects on milk yield, behavior, and heart rate at milking. Journal of Dairy Science 82: 720-727
Salama A A K, Such X, Caja G, Rovai M, Casals R, Albanell E, Marin M P \& Marti A (2003). Effects of once versus twice daily milking throughout lactation on milk yield and milk composition in dairy goats. Journal of Dairy Science 86: 1673-1680

Salama A A K, Caja G, Such X, Peris S, Sorensen A \& Knight C H (2004). Changes in cisternal udder compartment induced by milking interval in dairy goats milked once- or twice-daily. Journal of Dairy Science 87: 1181-1187

SAS (1999). Institute Inc., SAS Online Doc ${ }^{\circledR}$, Version 8, Cary, NC

Sinapis E (2007). The effect of machine or hand milking on milk production, composition and SCC in mountainous Greek breed (Boutsiko) ewes. Small Ruminant Research 69: 242-246

Torres A, Castro N, Hernández-Castellano L E, Argüello A \& Capote J (2012). Short communication: Effects of milking frequency on udder morphology, milk partitioning, and milk quality in 3 dairy goat breeds. Journal Dairy Science 96: 1071-1074

Torres A, Castro N, Argüello A \& Capote J (2013). Comparison between two milk distribution structures in dairy goats milked at different milking frequencies. Small Ruminant Research 114: 161-166

Torres A, Capote J, Argüello A, Sánchez-Macías D, Morales-delaNuez A \& Castro N (2014). Effects of oxytocin treatments on milk ejection in dairy goats traditionally milked once a day. Small Ruminant Research 120: 231-233

Tölü C \& Savaş T (2008). Süt keçiciliğinde makineyle sağım şart. Hasad Hayvancılık 281: 30-33

Tölü C, Yurtman İ Y \& Savaş T (2010). Gökçeada, Malta ve Türk Saanen keçi genotiplerinin süt verim özellikleri bakımından karşılaştırılması. Hayvansal Üretim 51(1): 8-15

Tölü C, Yurtman İ Y, Baytekin H, Ataşoğlu C \& Savaş $\mathrm{T}$ (2012). Foraging strategies of goats in a pasture of wheat and shrubland. Animal Production Science 52(12): 1069-1076

Zan M, Stibilj V \& Rogelj I (2006). Milk fatty acid composition of goats grazing on alpine pasture. Small Ruminant Research 64: 45-52 